Hussain A Obaidi BDS, MSc (Prof)

Manar Y Abdul-Qadir BDS, MSc (Assist Lect)

\section{Upper lip profile changes}

\author{
Dept of Pedod, orthod, and Prev Dentistry \\ College of Dentistry, University of Mosul \\ Dept of Pedod, orthod, and Prev Dentistry \\ College of Dentistry, University of Mosul
}

\begin{abstract}
Aims: To explore the upper lip thicknesses, height and it's relationship to the esthetic line. Materials and Methods: The studying sample included 48, 41, 50 and 44 individuals of age 11, 12, 13 and 14 years respectively. The subjects were Iraqi individuals of Class I normal occlusion, who live in center of Mosul City. All subjects were radiographed with lateral cephalometric films, these films were traced, the tracing included the upper lip thickness at skeletal points $\left(\mathrm{A}-\mathrm{A}^{\prime}\right)$, upper lip thickness at labrale superius (Ls-Ls'), upper lip height at stromion superior to palatal plane and the upper lip relationship to the esthetic line. All these measurements were measured and then subjected to the statistical analysis. Results: The results were demonstrated that the upper lip thickness (A-A') and (Ls-Ls') were only significant increase at 14 year age groups as compared with 11 years age group in males. In female the upper lip thickness was only significant at 13 years group as compared with 11 years age group, while the upper lip relationship to esthetic line showed only significantly greater value at 14 years age group as compared with 13 years age group. Sex variation appeared a significant greater value in male than female for the (Ls-E line) at 11 years age group, (A-A') and (Ls-E line) at 12 years age group, (Ls-Ls') at 13 years age group and upper lip height at 14 years age group and upper lip height at 14 years age group. Conclusions: The soft tissue of upper lip profile parameters were increased with increasing age group, and the upper lip significantly larger behind the esthetic line in female than male at 11,12 and 14 years age groups.

Key words: Endosteal Lip, thickness, height, esthetic.

Obaidi HA, Abdul - Qadir MY. Upper Lip Profile Changes. Al-Rafidain Dent J. 2007; 7(2): 153-159.

Received:3/4/2006 Sent to Referees:11/4/2006 Accepted for Publication:4/6/2006
A
\end{abstract}

\section{INTRODUCTION}

The soft tissues might have their inherent architecture, and that the midface soft tissue form and position appear to be less dependent on underlying hard tissue. ${ }^{(1)}$ The thickness of the lips are greater in males than females. ${ }^{(2)}$ Lip thickness is also strongly influence by ethnic characteristics. $^{(3,4)}$ Mean while, the normal lip projection is presented when the lips are inverted relative to their base and affected by lip thickness, dental protrusion or retrusion and maxillo-mandibular protrusion or retrusion. ${ }^{(3)}$ The orthodontic treatment with extraction procedures achieve more important changes in lip profile than in non extraction procedures ${ }^{(5-7)}$, whereas other authors reported that there is very little difference between extraction and non extraction orthodontic treatment on

The sample subjects met the selection soft tissue profile..$^{(1,8-9)}$

The aims of this study were to explore the upper lip profile parameters (upper lip; thicknesses, height and its distance to esthetic line).

\section{MATERIALS AND METHODS}

The sample was selected from 20 intermediate schools ( 11 for girls and 9 for boys) and 16 primary schools ( 8 for girls and 8 for boys) in the center of Mosul City. The criteria for the sample selected were: Full complement of permanent teeth excluding the third molars, normal occlusion Class I molar and canine relationship $^{(10)}$, normal overjet and overbite (1$4 \mathrm{~mm})^{(11)}$, no detectable crowding and rotation and spacing ${ }^{(12)}$, no apparent facial disharmony, no previous orthodontic treatment or maxillofacial surgery.

criteria was divided according to age into 
four groups; 11 years age group (23 males and 25 females), 12 years age group (19 males and 22 females), 13 years age group (22 males and 28 females) and 14 years age group (22 males and 22 females).

Each subject was radiographed with lateral cephalometric film in the Radiology Center in the Dental School / University of Mosul, with standardized manner for all the individuals. The lateral cephalometric radiographs of the sample subjects were traced. The tracing included: Upper lip thickness at point $\mathrm{A}\left(\mathrm{A}-\mathrm{A}^{\prime}\right)$, upper lip thickness at labrale superius (Ls-Ls') according to Nanda et al. ${ }^{(11)}$, upper lip height as described by Mamandras ${ }^{(13)}$, upper lip relationship to esthetic plane (Ls-E line) as described by Ricketts ${ }^{(14)}$; Figure (1).

The findings were analyzed by using the descriptive analysis that include: Mean; Standard deviation; Minimum and maximum values; Duncan Multiple Range Analysis of Variance, and Student's T-test analyses at $p \leq 0.05$, to find the difference among the upper lip profile parameters among the age groups and between sexes.

\section{RESULTS}

The descriptive statistics of the upper lip profile parameters demonstrated in Table (1), The variance analysis of parameters among the age groups and sex variation explored in Tables (2-5), and Table (6) respectively. The upper lip thickness at $\left(\mathrm{A}-\mathrm{A}^{\prime}\right)$ and at (Ls-Ls') showed significant increasing at 14 years age group, as compared with 11 year age group for the males. Where in females, the increased significances appeared at esthetic plane (Ls-E line) for 14 years age group when compared with the 11 years age group.

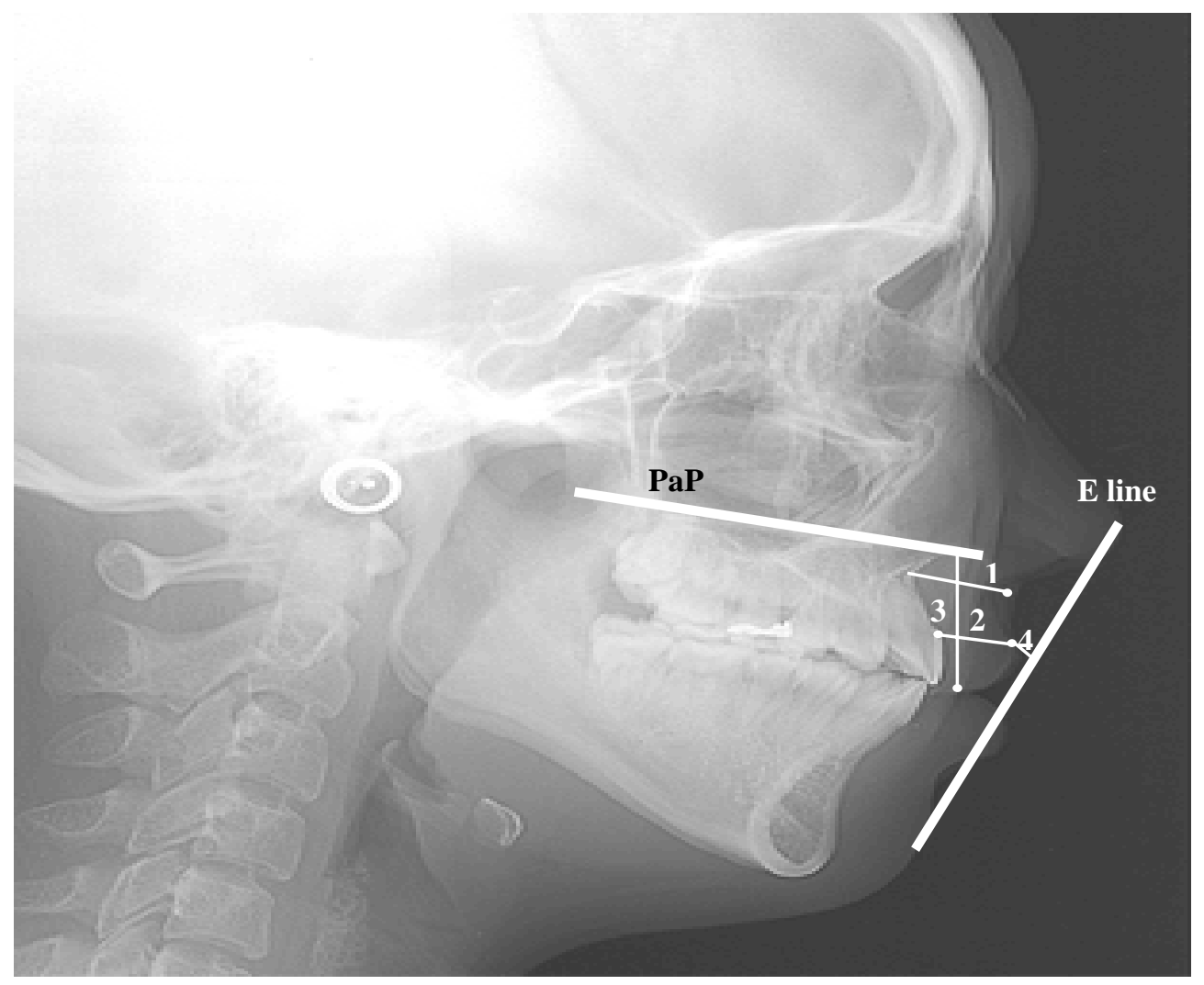

Figure (1): Soft tissue linear measurements.

1: Upper lip thickness at A ( A-A '); 2: Upper lip thickness at (Ls-Ls'); 3: Upper Lip Height; 4: Lower superioris point of the upper lip-Esthetic line. 
Table (1): Descriptive statistics for the soft tissue variables of males and females, with four age groups.

\begin{tabular}{|c|c|c|c|c|c|c|c|}
\hline Age group & Variable & Examination & Number & Minimum & Maximum & Mean & \pm Sd \\
\hline \multirow{8}{*}{$\begin{array}{c}11 \\
\text { years }\end{array}$} & \multirow{2}{*}{$\mathbf{A}-\mathbf{A}^{\prime}$} & Male & 23 & 13 & 18 & 15.63 & 1.04 \\
\hline & & Female & 25 & 13 & 19 & 15.32 & 1.32 \\
\hline & \multirow{2}{*}{ Ls-Ls' } & Male & 23 & 12 & 15 & 13.52 & 0.96 \\
\hline & & Female & 25 & 10 & 15 & 13.12 & 1.39 \\
\hline & \multirow{2}{*}{$\begin{array}{c}\text { Upper Lip } \\
\text { Height }\end{array}$} & Male & 23 & 21.5 & 27 & 24.39 & 1.39 \\
\hline & & Female & 25 & 19 & 27 & 23.58 & 2.22 \\
\hline & \multirow{2}{*}{ Ls-E line } & Male & 23 & -5 & 1 & -1.07 & 1.45 \\
\hline & & Female & 25 & -4.5 & 1 & -2.12 & 1.40 \\
\hline \multirow{8}{*}{$\begin{array}{c}12 \\
\text { years }\end{array}$} & \multirow{2}{*}{$\mathbf{A}^{-\mathbf{A}^{\prime}}$} & Male & 19 & 14 & 19 & 16.55 & 1.39 \\
\hline & & Female & 22 & 12.5 & 17 & 15.39 & 1.20 \\
\hline & \multirow{2}{*}{ Ls-Ls` } & Male & 19 & 11 & 17.5 & 14.32 & 2.00 \\
\hline & & Female & 22 & 10 & 15.5 & 13.41 & 1.42 \\
\hline & \multirow{2}{*}{$\begin{array}{c}\text { Upper Lip } \\
\text { Height }\end{array}$} & Male & 19 & 21.5 & 29 & 25.39 & 2.05 \\
\hline & & Female & 22 & 20 & 30 & 24.45 & 2.58 \\
\hline & \multirow{2}{*}{ Ls-E line } & Male & 19 & -4 & 0.5 & -1.42 & 1.30 \\
\hline & & Female & 22 & -6 & 0.5 & -2.93 & 1.74 \\
\hline \multirow{8}{*}{$\begin{array}{c}13 \\
\text { years }\end{array}$} & \multirow{2}{*}{ A-A } & Male & 22 & 14 & 20 & 16.59 & 1.69 \\
\hline & & Female & 28 & 12 & 19 & 15.64 & 1.68 \\
\hline & \multirow{2}{*}{ Ls-Ls' } & Male & 22 & 11.5 & 18 & 14.70 & 1.90 \\
\hline & & Female & 28 & 10 & 18.5 & 13.41 & 1.86 \\
\hline & \multirow{2}{*}{$\begin{array}{c}\text { Upper Lip } \\
\text { Height }\end{array}$} & Male & 22 & 21 & 30 & 25.50 & 2.89 \\
\hline & & Female & 28 & 22 & 30 & 25.68 & 1.67 \\
\hline & \multirow{2}{*}{ Ls-E line } & Male & 22 & -5.5 & 1.5 & -2.00 & 1.91 \\
\hline & & Female & 28 & -6 & 0 & -2.88 & 1.75 \\
\hline \multirow{8}{*}{$\begin{array}{c}14 \\
\text { years }\end{array}$} & \multirow{2}{*}{$\mathbf{A}-\mathbf{A}^{\prime}$} & Male & 22 & 13 & 21 & 17.05 & 1.98 \\
\hline & & Female & 22 & 11 & 19 & 16.30 & 1.97 \\
\hline & \multirow{2}{*}{ Ls-Ls' } & Male & 22 & 12 & 18 & 15.02 & 1.78 \\
\hline & & Female & 22 & 8 & 18 & 14.02 & 2.22 \\
\hline & \multirow{2}{*}{$\begin{array}{c}\text { Upper Lip } \\
\text { Height }\end{array}$} & Male & 22 & 21 & 30 & 26.16 & 2.56 \\
\hline & & Female & 22 & 21 & 27 & 24.64 & 1.60 \\
\hline & \multirow{2}{*}{ Ls-E line } & Male & 22 & -4 & 0 & -1.93 & 1.17 \\
\hline & & Female & 22 & -7 & 1 & -3.86 & 1.98 \\
\hline
\end{tabular}

( A-A'): Upper lip thickness; Ls-Ls: Upper lip thickness 'Note: All measurements in $\mathrm{mm}$; Sd: Stander deviation.

Table (2): Duncan's Multiple Range Test of variance, For A-A' variable, with the four age groups.

\begin{tabular}{cccccc}
\hline Sex & Age Groups Number & Mean & \pm Sd & Duncan's Test* \\
\hline \multirow{5}{*}{ Male } & 11 Years & 23 & 15.630 & 1.036 & $\mathrm{a}$ \\
& 12 Years & 19 & 16.553 & 1.393 & $\mathrm{ab}$ \\
& 13 Years & 22 & 16.591 & 1.688 & $\mathrm{ab}$ \\
& 14 Years & 22 & 17.045 & 1.982 & $\mathrm{~b}$ \\
\hline \multirow{5}{*}{ Female } & 11 Years & 25 & 15.320 & 1.322 & $\mathrm{a}$ \\
& 12 Years & 22 & 15.386 & 1.204 & $\mathrm{a}$ \\
& 13 Years & 28 & 15.643 & 1.682 & $\mathrm{a}$ \\
& 14 Years & 22 & 16.295 & 1.968 & $\mathrm{a}$ \\
\hline
\end{tabular}

For males: $\mathrm{F}$-value $=3.25, p$-value $=0.026$, Significant at $p \leq 0.05$; For females: $\mathrm{F}-$ value $=$ $1.81, p-$ value $=0.151$, Not Significant at $p>0.05 ; *$ Means with the same letters were statistically not significant; Sd: Stander deviation. 


\section{DISCUSSION}

The soft tissue thickness of upper lip at point $\mathrm{A}$, and at Ls in males showed higher values with increasing age group. Significantly higher values were noticed at 14 years group as compared to 11 years group indicating increasing lip thickness with age. These findings were supported by those of Prahl-Andersen et al. ${ }^{(15)}$, who demonstrated a continued increase in upper lip thickness at point A, and at Ls from 9 to 14 years in males. Females also demonstrated higher values for upper lip thickness at point $\mathrm{A}$, and at Ls with increasing age group; With no significant difference noticed among the four age groups. This came in agreement with the findings of Prahl-Andersen et al. ${ }^{(15)}$, who showed increased lip thickness in females from 9 to 14 years. In comparing the value for both sexes, males demonstrated higher values than females in the four age groups. This difference reached the level of significance only at 12 years group for (A$\left.\mathrm{A}^{\prime}\right)$ dimension, and at 13 years group for (Ls-Ls') dimension. These findings were consistent with some authors findings ${ }^{(2,15,}$ ${ }^{16)}$, who showed thicker upper lips in males than in females.

Table (3): Duncan's Multiple Range Test of variance,

For Ls-Ls`variable, with the four age groups.

\begin{tabular}{cccccc}
\hline Sex & Age Groups Number & Mean & \pm Sd & Duncan's Test* \\
\hline \multirow{4}{*}{ Male } & 11 Years & 23 & 13.522 & 0.959 & $\mathrm{a}$ \\
& 12 Years & 19 & 14.316 & 2.001 & $\mathrm{ab}$ \\
& 13 Years & 22 & 14.705 & 1.900 & $\mathrm{ab}$ \\
& 14 Years & 22 & 15.023 & 1.783 & $\mathrm{~B}$ \\
\hline \multirow{5}{*}{ Female } & 11 Years & 25 & 13.120 & 1.387 & $\mathrm{~A}$ \\
& 12 Years & 22 & 13.409 & 1.420 & $\mathrm{~A}$ \\
& 13 Years & 28 & 13.411 & 1.861 & $\mathrm{~A}$ \\
& 14 Years & 22 & 14.023 & 2.217 & $\mathrm{~A}$ \\
\hline
\end{tabular}

For males: $\mathrm{F}$-value $=3.31, p-$ value $=0.024$, Significant at $p \leq 0.05 ;$ For females: $\mathrm{F}$-value $=1.08$, $p$-value $=0.360$, Not Significant at $p>0.05 ; *$ Means with the same letters were statistically not significant; Sd: Stander deviation.

Table (4): Duncan's Multiple Range Test of variance, For upper lip height variable, with the four age groups.

\begin{tabular}{cccccc}
\hline Sex & Age Groups Number & Mean & $\underline{ \pm} \mathbf{S d}$ & Duncan's Test* \\
\hline \multirow{5}{*}{ Male } & 11 Years & 23 & 24.391 & 1.390 & $\mathrm{a}$ \\
& 12 Years & 19 & 25.395 & 2.045 & $\mathrm{a}$ \\
& 13 Years & 22 & 25.500 & 2.890 & $\mathrm{a}$ \\
& 14 Years & 22 & 26.159 & 2.556 & $\mathrm{a}$ \\
\hline \multirow{5}{*}{ Female } & 11 Years & 25 & 23.580 & 2.221 & $\mathrm{a}$ \\
& 12 Years & 22 & 24.455 & 2.582 & $\mathrm{Ab}$ \\
& 13 Years & 28 & 25.679 & 1.668 & $\mathrm{~B}$ \\
& 14 Years & 22 & 24.636 & 1.605 & $\mathrm{Ab}$ \\
\hline
\end{tabular}

For males: $\mathrm{F}-$ value $=2.31, p$-value $=0.082$, Significant at $p \leq 0.05$; For females: $\mathrm{F}$-value $=4.72$, $p$-value $=0.004$, Not Significant at $p>0.05 ; *$ Means with the same letters were statistically not significant; Sd: Stander deviation. 
Table (5): Duncan's Multiple Range Test of variance, For Ls-E line, with the four age groups.

\begin{tabular}{|c|c|c|c|c|c|}
\hline & Age Groups & imber & Mean & \pm Sd & Duncan's Test* \\
\hline \multirow{4}{*}{ Male } & 11 Years & 23 & -1.065 & 1.448 & $\mathrm{~A}$ \\
\hline & 12 Years & 19 & -1.421 & 1.305 & A \\
\hline & 13 Years & 22 & -2.000 & 1.909 & A \\
\hline & 14 Years & 22 & -1.932 & 1.168 & A \\
\hline \multirow{4}{*}{ Female } & 11 Years & 25 & -2.120 & 1.401 & $\mathrm{~A}$ \\
\hline & 12 Years & 22 & -2.932 & 1.741 & $\mathrm{Ab}$ \\
\hline & 13 Years & 28 & -2.875 & 1.746 & $\mathrm{Ab}$ \\
\hline & 14 Years & 22 & -3.864 & 1.977 & $\mathrm{~B}$ \\
\hline
\end{tabular}

Table (6): Student's T-test for the soft tissue variables between males and females for the four age groups.

\begin{tabular}{|c|c|c|c|c|c|c|c|}
\hline Age groups & Variable & Examination & Number & Mean & $\pm \mathrm{Sd}$ & T-test & $p$ value \\
\hline \multirow{8}{*}{11 years } & \multirow{2}{*}{ A-A } & Male & 23 & 15.63 & 1.04 & \multirow{2}{*}{0.90} & \multirow{2}{*}{0.37} \\
\hline & & Female & 25 & 15.32 & 1.32 & & \\
\hline & \multirow{2}{*}{ Ls-Ls` } & Male & 23 & 13.52 & 0.96 & \multirow[b]{2}{*}{1.16} & \multirow{2}{*}{0.25} \\
\hline & & Female & 25 & 13.12 & 1.39 & & \\
\hline & \multirow{2}{*}{$\begin{array}{c}\text { Upper Lip } \\
\text { Height }\end{array}$} & Male & 23 & 24.39 & 1.39 & \multirow{2}{*}{1.50} & \multirow{2}{*}{0.14} \\
\hline & & Female & 25 & 23.58 & 2.22 & & \\
\hline & \multirow{2}{*}{ Ls-E line } & Male & 23 & 44.52 & 2.58 & \multirow{2}{*}{2.08} & \multirow{2}{*}{$0.043^{+}$} \\
\hline & & Female & 25 & 42.94 & 2.67 & & \\
\hline \multirow{8}{*}{12 years } & \multirow{2}{*}{ A-A } & Male & 19 & 16.55 & 1.39 & \multirow{2}{*}{2.88} & \multirow{2}{*}{$0.0065^{+}$} \\
\hline & & Female & 22 & 15.39 & 1.20 & & \\
\hline & \multirow{2}{*}{ Ls-Ls' } & Male & 19 & 14.32 & 2.00 & \multirow{2}{*}{1.69} & \multirow{2}{*}{0.099} \\
\hline & & Female & 22 & 13.41 & 1.42 & & \\
\hline & \multirow{2}{*}{$\begin{array}{l}\text { Upper Lip } \\
\text { Height }\end{array}$} & Male & 19 & 25.40 & 2.05 & \multirow{2}{*}{1.28} & \multirow{2}{*}{0.21} \\
\hline & & Female & 22 & 24.46 & 2.58 & & \\
\hline & \multirow{2}{*}{ Ls-E line } & Male & 19 & -1.42 & 1.30 & \multirow{2}{*}{3.10} & \multirow{2}{*}{$0.0069^{+}$} \\
\hline & & Female & 22 & -2.93 & 1.74 & & \\
\hline \multirow{8}{*}{13 years } & \multirow{2}{*}{$\mathbf{A}-\mathbf{A}^{\prime}$} & Male & 22 & 16.59 & 1.69 & \multirow{2}{*}{1.98} & 0054 \\
\hline & & Female & 28 & 15.64 & 1.68 & & 0.054 \\
\hline & & Male & 22 & 14.71 & 1.90 & 242 & $0019^{+}$ \\
\hline & LS-LS & Female & 28 & 13.41 & 1.86 & 2.42 & 0.019 \\
\hline & Upper Lip & Male & 22 & 25.50 & 2.89 & 007 & 034 \\
\hline & Height & Female & 28 & 25.68 & 1.67 & -0.91 & 0.34 \\
\hline & Is_F line & Male & 22 & -2.00 & 1.91 & 169 & 0098 \\
\hline & Ls-E Ine & Female & 28 & -2.88 & 1.75 & 1.09 & 0.098 \\
\hline & A_A: & Male & 22 & 17.05 & 1.98 & 126 & 021 \\
\hline & A-A & Female & 22 & 16.30 & 1.97 & 1.20 & 0.21 \\
\hline & & Male & 22 & 15.02 & 1.78 & 165 & 011 \\
\hline 14 vears & LS-LS & Female & 22 & 14.02 & 2.22 & 1.65 & 0.11 \\
\hline 14 yedrs & Upper Lip & Male & 22 & 26.16 & 2.56 & 237 & $0023^{+}$ \\
\hline & Height & Female & 22 & 24.64 & 1.60 & 2.31 & 0.023 \\
\hline & Ls-E line & Male & 22 & -1.93 & 1.17 & 3.95 & $0.0003^{+}$ \\
\hline & & Female & 22 & -3.86 & 1.98 & & \\
\hline
\end{tabular}

( $\left.\mathrm{A}-\mathrm{A}^{\prime}\right)$ : Upper lip thickness; Ls-Ls: Upper lip thickness

Note: All measurements in mm; Sd: Stander deviation; ${ }^{+}$Significant differences between males and females $(p \leq 0.05)$. 
In males upper lip height showed higher values with increasing age group with no significance. It can be concluded that upper lip height increased with age and this agreed with the findings of Mamandras ${ }^{(13)}$ and Vig and Cohen ${ }^{(17)}$, who reported a gradual increase in upper lip height from 10 to 14 years in males. Females showed higher value for upper lip height at 12 years group than 11 years group. It was showed higher value at 13 years group than 11 and 12 years group with significant difference noticed between 11 and 13 years group. At 14 years upper lip height value was lower than that at 13 years but larger than the values for 11 years and 12 years groups. Generally, it was noticed that upper lip height increased in females with increasing age group. This came in agreement with the findings of the researchers ${ }^{(13,17)}$, who showed an increase in upper lip height from 10 to 14 years in females. In comparing the values of males and females, males displayed higher values for upper lip height than females at 11 , 12 and 14 years groups with significance noticed at 14 years group. Females, however showed higher value (by $0.18 \mathrm{~mm}$ ) than males at 13 years group. Generally, this indicates a longer upper lip in males than females which agreed with the findings of Mamandras ${ }^{(13)}$, who showed greater upper lip height in males than females at 10,12 and 14 years with significance noticed at 14 years. On the other hand, Subtelny ${ }^{(18)}$ showed no difference between male and female subjects relative to this measurement.

An evaluation of the upper lip relative to the esthetic plane in males showed a greater distance of upper lip behind this line from 11 years group to 13 years group. At 14 years group the value was smaller than that at 13 years group by 0.06 $\mathrm{mm}$. No significant difference was noticed among the four age groups. These findings indicated a more posterior position of Ls relative to E-line with increasing age group and this coincided with the findings of Nanda, Bishara and others ${ }^{(11,19)}$, who showed a gradual retrusion of upper lip relative to this plane from 11 to 14 years in males. In females, upper lip showed greater distance behind the E-line at 12 years group compared to 11 years group. At 13 years group the distance was less than that at 12 years group by $0.05 \mathrm{~mm}$. At 14 years group Ls showed greater distance behind the E-line than the other three groups; With significant difference noticed between 11 years and 14 years groups. These findings indicate a more posteriorly positioned upper lip relative to the esthetic plane with increasing age group. Similar findings were reported by Nanda et al. ${ }^{(11)}$ and Bishara et al. ${ }^{(20)}$ for females from 11 to 14 years.

The comparison between males and females revealed a greater distance of Ls behind the (E-line) in females than in males in the four groups with significance noticed at 11, 12 and 14 years groups. This indicates a more retrusive upper lips in females than in males relative to this plane and it is consistent with the findings of Bishara et al. ${ }^{(19,20)}$

\section{CONCLUSIONS}

Males and females, showed significantly higher values at 14 years age group for (A-A') and (Ls-Ls') than 11 years age group. Sexes variations revealed that the upper lip significantly larger behind the esthetic line in female than male at 11,12 and 14 years age groups.

\section{REFERENCES}

1. Moseling KP, Woods MG. Lip curve changes in females with premolar extraction or non extraction treatment. Angle Orthod. 2004; 74(1): 51-62.

2. Saglam AMS, Gazilerli U. Analysis of Holdaway soft tissue measureements in children between 9 and 12 years of age. Eur J Orthod. 2001; 23: 287-294.

3. Sarver DM. Esthetic Orthodontic and Orthognathic Surgery. Mosby YearBook. 1998; Pp: 63-73.

4. Proffit WR. Contemporary Orthodontics. $3^{\text {rd }}$ ed.Mosby.2000;Pp:30,40-42,161, 171.

5. Kocadereli I. Changes in soft tissue profile after treatment with and without extractuions. Am $J$ Orthod Dentofac Orthop. 2002; 122(1): 67-72.

6. Hazar S, Akyalcin S, Boyacisglu H. Soft tissue profile changes in Anatolian Turkish girls and boys following orthodontic treatment with and without extractions. Turk J Med Sci. 2004; 34: 171-178. 
7. Basciftci FA, Uysal T, Buyukerkmen A, Demir A. The influence of extraction treatment on holdaway soft tissue measurements. Angle Orthod. 2004; 74(2): 167-173.

8. Ismail SFH, Moss JP. Three dimensional effects of orthodontic treatment on the facial soft tissue: A preliminary study. $\mathrm{Br}$ Dent J. 2002; 192(2): 104-108.

9. Wholley CJ, Woods MG. The effects of commonly prescribed premolar extraction sequences on the curvature of the upper and lower lips. Angle Orthod. 2003; 73(4): 386-395.

10. Kerr WJS. A longitudinal cephalometric study of dentofacial growth from 5 to 15 years. Br J Orthod. 1979; 6: 115-121.

11. Nanda RS, Meng H, Kapila S, Goorhuis J. Growth changes in the soft tissue facial profile. Angle Orthod. 1990; 60(3): 177190.

12. Axelsson S, Kjaer I, Bjornland T, Storhaug K. Longitudinal cephalometric standards for the neurocranium in Norwegians from 6 to 21 years of age. Eur $J$ Orthod. 2003; 25: 185-198.

13. Mamandras AH. Linear changes of the maxillary and mandibular lips. Am $J$ Orthod Dentofac Orthop. 1988; 94(5):
405-410.

14. Ricketts RM. Esthetics, environment and the law of lip relations. Am J Orthod. 1968; 54(4): 272-289.

15. Prahl-Andersen B, Ligthelm-Bakker ASWMR, Wattel E, Nanda K. Adolescent growth changes in soft tissue profile. Am J orthod Dentofac Orthop. 1995; 107(5): 476-483.

16. Genecov JS, Sinclair PM, Dechow PC. Development of the nose and soft tissue profile. Angle Orthod. 1990; 60(3): 191198.

17. Vig PS, Cohen AM. Vertical growth of the lips: A serial cephalometric study. $\mathrm{Am}$ J Orthod. 1979; 75(4): 405-415.

18. Subtelny JD. A longitudinal study of the soft tissue facial structures and their profile characteristics defined in relation to underlying structures. Am J Orthod. 1959; 45(7): 581-607.

19. Bishara SE, Jackobsen JR, Hession TJ, Treder JE. Soft tissue profile changes from 5-45 years of age. Am J Orthod Dentofac Orthop. 1998; 114(6): 698-706.

20. Bishara SE, Hession TJ, Peterson LC. Longitudinal soft tissue profile changes: A study of three analyses. Am J Orthod. 1985;88(3): 209-223. 